\title{
Micromorphological Evidence of Neolithic Rondel-like Ditch Infillings. Case Studies from Těšetice-Kyjovice and Kolín, Czech Republic
}

\author{
Lenka Lisáa $^{*}$, Aleš Bajer ${ }^{\mathrm{b}}$, David Válek ${ }^{\mathrm{c}}$, Petr Květina ${ }^{\mathrm{d}}$, Radka Šumberovád \\ aInstitute of Geology AS CR, v. v. i., Rozvojová 269, Prague 6, 165 00, Czech Republic \\ ${ }^{b}$ Institute of Geology and Pedology, Faculty of Forestry and Wood Technology, Mendel University, Zemédělská 3, 613 00 Brno, Czech Republic \\ 'Institute of Archaeology and Museology, Faculty of Arts, Masaryk University, Arne Nováka 1, 60200 Brno, Czech Republic \\ ${ }^{d}$ Institute of Archaeology AS CR, v. v. i., Letenská 4, Prague, Czech Republic
}

\section{ARTICLE INFO}

\section{Article history:}

Received: 2. October 2013

Accepted: 2. December 2013

\section{Key words:}

formation processes

sedimentology

micromorphology

Neolithic rondel structures

STK (Stroked pottery culture)

Lengyel culture

Czech Republic

\begin{abstract}
This case study discusses the formation processes which conceivably took place during the formation of the infilling of Neolithic rondel ditches. These processes were studied not only from a sedimentological point of view but primarily by means of a micromorphological approach which allowed us to distinguish the synsedimentary and postsedimentary processes more precisely and the formation of textural features macroscopically visible in the section. Different events documenting the phases of stability and erosion phases of various intensity were documented. Geomorphology and possible human impact are also discussed.
\end{abstract}

\section{Introduction}

Monumental features indirectly documenting changes in the structure of society at that time are represented in the Central European Neolithic period, in particular its later phases (4900-4500 BC) typically by the STK - Stroked pottery culture and Lengyel culture (Moravian painted ware culture). Composed of several construction elements, this type of feature is typically referred to as a "rondel" in the Czech environment (Pavlů 1982; Podborský 1988; Podborský 1999; terms used in foreign literature include Kreisgrabenanlage, circular ditches, circular enclosures, woodhenges, etc). A "classic" Late Neolithic rondel is typically considered a complex of one or several, more or less round, ditches with a characteristic sharp profile, and one or more circular concentric channels inside the space demarcated by the ditch with the smallest diameter. The

*Corresponding author. E-mail: lisa@gli.cas.cz maximum diameter of these objects is $30-240$ metres, the width of the ditches varies between 1.5-14 metres and their depth is usually between 1 to 4.5 metres. If there is more than one ditch, then the inner one is the widest and deepest (Ǩídký et al. 2012). Excavation results indicate that a palisade was once set in these channels. The existence of earthworkramparts inside the rondel or, rather, outside the ditches, is a topic under discussion which has not as yet been reliably proven.

These features, the construction of which required, according to the prevailing consensus, certain mathematical or even astronomical knowledge (most recently in Daim, Neubauer, Eds. 2005, 73-79), were only built in certain settlement areas. It is precisely this exclusivity connected with the assumed organized and centrally planned construction which makes rondels important indicators of Neolithic social complexity (e.g. H. Stäuble in: Bartels et al. 2003, 133). Twenty four rondels in all were detected within the territory of the Czech Republic up until the end of 2009 (Ŕídký 2011). 
The sedimentary infillings of rondel ditches are usually the only data archive available for further interpretations of rondel function and design. They look quite similar. The lower part is usually laminated with the thickness of the lamina varying from $\mathrm{mm}$ to $\mathrm{cm}$, while the upper part of the infilling is more or less homogenous (Zeman, Havlíček 1988). The high amount of material excavated from the ditch suggests the presence of earthwork in close proximity to the ditch (Kovárník, Mangel 2013; Lenneis 1977; Modderman 1983; Němejcová-Pavúková 1986; Neugebauer 1986; Oliva 2004; Válek et al. in print), although there are also authors suggesting that the earthworks were not present (Trnka 1986). Kovárník, Mangel (2013) and Vokolek (1963) described one of the rondel structures near Třebovětice with still preserved earthworks located on the outer side of the ditch. The relicts of earthworks were also documented in certain cases by aerial photography as lighter circles usually located on the outer side of the ditch. The location of the earthwork and its appearance is also a topic under question. A number of authors have suggested its location on the inner part of the ditch, while others have spoken of the outer part of the ditch. Although rondel structures as one type of monumental architecture look extremely similar, they on the other hand can vary to some degree and it is also quite possible that smaller earthworks were built on both sides of the ditch as it is visible on aerial photography in certain cases (Kovárník, Mangel 2013) or as found during the excavations (Zeman, Havlíček 1988).

How can one read the sedimentary archive of the ditch infillings? One basic approach is to distinguish lithological differences between layers and describe their appearance in a set of sections. This will serve to suggest the direction of the mass movement, while the lithological composition will relate of the provenance of the sediment transported into the ditch. These data were published numerous times suggesting the prevailing erosion of loess rich material or soil rich material, in all probability from nearby earthwork. The method of micromorphology used as the main methodological tool of this paper will probe more deeply into the processes taking place during the sedimentation. We would like to demonstrate how different phases of erosion and stabilisation of the ditch walls and the surrounding of the ditch can be recognised and how the different facial types commonly excavated in such structures can be read.

\section{Methods}

Archaeological excavations were carried out by Masaryk University in the case of Těsetice and by the Institute of Archaeology of the Academy of Sciences in Prague in the case of the Kolín rondel. The cleaned sections were sedimentologically described and documented. Five micromorphological samples from Těšetice were taken from primarily lithologically in the first stage of the project varied horizons and seven micromorphological samples from the third ditch of Kolín rondel were taken from the main part of the laminated body of the infilling. The samples were taken in situ into Kubiena boxes, slowly dried and impregnated in the Laboratory of Geoarchaeology, Institute of Geology AS CR, v. v. i. in Prague. Thin sections of a dimension of $120 \times 70 \mathrm{~mm}$ were completed by Julie Boreham in Reach (www.earthslides. com) and consequently studied under a binocular and polarising microscope (PPL, XPL and OIL) at magnifications in a range of 1-400×. A micromorphological description was made according to Bullock et al. (1985) and Stoops (2003).

\section{Site description and results}

\subsection{Case study Těšetice-Kyjovice}

The Těšetice-Kyjovice Neolithic rondel (Figure 1) is located on the south-east oriented slope in an area named Sutny I. It was the most important part of a local settlement dated to the first stage of the Moravian painted ware culture (phase Ia). Nearly all the sediments of ditch infilling apart from one 10 metre long segment in the north-east part have already been excavated. This was the first time in Central Europe when such a rondel structure was systematically studied (Podborský 1988). The final interpretations of the formation processes of the infilling were made on the basis of twenty control sections (Podborský 1988) by Zeman and Havlíček (1988). They distinguished three different sets of layers and interpreted them as the maintenance layer at the base followed by thick set of layers composed of washouts and terminated by layers which originated as a levelling layer. Válek et al. (2013) consequently carried out the revision of the formation processes and recognized two main horizons.

The micromorphological samples document the formation processes of the primary lithological types distinguished in the infilling. The micromorphological description is indicated in Table 1 and documented by Figures 1 and 3 . The uppermost part of the infilling is composed of highly bioturbated matrix (Table 1, sample 1, Figure 1A). It is evident that the material belongs to the redeposited soil which underwent the new pedogenesy. The channel microstructure (Figure 3A) and excrements of microfauna (Figure 3B) were documented. The horizons composing the infilling of the ditch, documented below (Table 1, samples 2 , 3, 4 and partly 5), were developed due to the deposition under the slope (Figure 3D). The difference between them depends on the type of material deposited into the ditch. The dark horizons are composed of the redeposited A horizon, only partially stabilised by vegetation. During the relatively quick deposition due to the disruption of the surface of the source area loess material from the walls was also partly eroded, while the roundness of the soil clasts is due to the gravitation. The light material represents the product of the degradation of loess walls or earthwork near the ditch due to the rainsplash lately influenced by seasonal frost activity and producing platy to lenticular microstructure (Figure 3C). The very bottom of the ditch infilling contains subrounded clasts of redeposited B horizon of Eemian luvisol (Table 1, samples 4 and 5, Figure 3D). The B horizon of Eemian soil 
Table 1. Micromorphological description and interpretations of samples from the Těšetice-Kyjovice rondel.

\begin{tabular}{ll}
\hline Sample/horizon & \multicolumn{1}{c}{ Description } \\
\hline $\begin{array}{l}\text { Sample 1, depth } \\
\text { of 10-20 cm }\end{array}$ & $\begin{array}{l}\text { Complex microstructure, partly channel and partly } \\
\text { subangular microstructure; voids: channels }(10 \%) \text {, vughs } \\
(5 \%), \text { cracks }(5 \%) \text { and compound packing voids }(50 \%) .\end{array}$ \\
& C/F $(50 \mu \mathrm{m})=30: 70$, loam. Brown matrix, B fabricstipple \\
& speckled occasionally cross striated. Microcharcoal (5\%), \\
& decomposed dark (5\%) and light (5\%) organic matter and \\
& partly decomposed organic matter (1\%). Phytoliths presented \\
& but rare, high bioturbation, presented FeOH accumulations \\
& $(3 \%)$, no carbonate accumulations.
\end{tabular}

Sample 2, depth Channel to granular microstructure, voids: channels $(20 \%)$, of $160-170 \mathrm{~cm} \quad$ compound packing voids $(50 \%) . \mathrm{C} / \mathrm{F}(50 \mu \mathrm{m})=30: 70$, loam. Matrix light brown to grey, composed of carbonates, part of the matrix (20\%) is brownish. Crystalic B fabric. Microcharcoal presented but rare (1\%), decomposed dark (10-15\%) and light (5\%) organic matter and partly decomposed organic matter (1\%). Phytoliths presented but rare, carbonate accumulations in the form of coatings, hypocoatings, infillings. Bioturbation observed with microfauna excremental pellets. Rarely angular clasts of dark brown matrix with decomposed organic matter documented. Left part of the sample is composed of loess representing the geological background of the locality.

Sample 3, darker Channel to granular, partly platy microstructure composed horizons, depth of subrounded clasts of light and dark matrix. Preferred of 200-202 cm; orientation within clasts due to the bioturbation. Voids: $203-206 \mathrm{~cm} \quad$ channels, mainly within dark clasts $(20 \%)$ and compound packing voids $(50 \%) . \mathrm{C} / \mathrm{F}(50 \mu \mathrm{m})=30: 70$, loam. Brown to dark brown matrix with crystalic and partly stipple speckled B fabric. Shell fragments documented. Microcharcoal presented but rare (1\%), decomposed dark (10-15\%) and light $(5 \%)$ organic matter and partly decomposed organic matter (1\%). Phytoliths presented but rare, carbonate accumulations in the form of coatings, hypocoatings and infillings. Bioturbation presented and also excremental pellets of microfauna. Accumulations of calcium carbonate presented in the form of coating and fine grained concentrations within the matrix. Redeposited calcium carbonated accumulations detected.

Sample 3, lighter Massive, partly platy microstructure with porphyric related horizons, depth distribution. Voids: channels (3\%). Preferred orientation of 202-203, 206-210 of clasts. $\mathrm{C} / \mathrm{F}(50 \mu \mathrm{m})=30: 70$, loam. Light brown matrix with non diferenciated B fabric, just occasionally crystalic. Organic matter decomposed dark (3\%) and light (3\%). Calcium carbonated concentration within matrix rare.

Sample 4, depth Complex microstructure with granular and chamber types of 254-260 cm. of microstructure. Voids: channels (20\%) and compound packing voids $(50 \%)$. $\mathrm{C} / \mathrm{F}(50 \mu \mathrm{m})=30: 70$, loam. Matrix vary from light brown where carbonates dominate, to brown and darker brown (depends on the percentage of decomposed fine grained organic matter). Subangular clasts detected in this horizon have a light orange colour. B fabric is crystalic, partly cross striated. Microcharcoal presented (5\%), decomposed dark (10-15\%) and light (5\%) organic matter and partly decomposed organic matter (1\%). Phytoliths presented but rare, carbonate accumulations in the form of coatings, hypocoatings and infillings.
Highly bioturbated horizon of redeposited soil recently covered by vegetation. Rarely presented angular clasts come from A horizon of black earth like soil. No standing water environment detected.
Fig. 1 Fig. 3B, C
Layers developed due to the deposition under the slope. The difference between them depends on the type of material deposited into the ditch. Dark horizons are composed of redeposited A horizon, just partly stabilised by vegetation. During the relatively quick deposition due to the disruption of the surface of the source area also loess material from the walls was partly eroded, the roundness of the soil clasts is due to the gravitation. The light material represents the product of degradation of loess walls or earthwork near the ditch due to the rainspash lately influenced by seasonal frost action and producing platy microstructure. The upper three $\mathrm{cm}$ of sample 4 contain two light and one dark horizon comparable with those described within sample 3 .
Fig. 1

Fig. 3C Bioturbated material composed of
redeposited loess and soil material and
also subrounded clasts of redeposited B horizon of Eemian luvisol. Redeposition probably under rainsplash, but lately highly bioturbated. The presence of B horizon suggests the redeposition from the earthworks where the excavated material was deposited.
Fig. 1

Fig. 3D 
Table 1. Micromorphological description and interpretations of samples from the Těšetice-Kyjovice rondel (continue).

\begin{tabular}{|c|c|c|c|}
\hline Sample/horizon & Description & Interpretation & $\begin{array}{c}\text { Photo } \\
\text { documentation }\end{array}$ \\
\hline $\begin{array}{l}\text { Sample 5, depth } \\
\text { of } 300-307 \mathrm{~cm}\end{array}$ & $\begin{array}{l}\text { Angular blocky to chamber microstructure with granular and } \\
\text { chamber types of microstructure. Voids: cracks }(10 \%) \text { and } \\
\text { channels }(20 \%) \text { and compound packing voids }(50 \%) \text {. } \\
\mathrm{C} / \mathrm{F}(50 \mu \mathrm{m})=30: 70 \text {, loam. Gray to light brown (partly orange) } \\
\text { highly calcified matrix with crystalic B fabric, occasionally } \\
\text { cross striated B fabric. Microcharcoal presented }(5 \%) \text {, } \\
\text { decomposed dark }(10-15 \%) \text { and light }(5 \%) \text { organic matter } \\
\text { and partly decomposed organic matter }(1 \%) \text {. Phytoliths } \\
\text { presented but rare, carbonate accumulations in the form of } \\
\text { coatings, hypocoatings and infillings and FeOH nodules. }\end{array}$ & $\begin{array}{l}\text { Bioturbated material composed of } \\
\text { redeposited loess and soil material and } \\
\text { also subrounded clasts of redeposited } \\
\text { B horizon of Eemian luvisol, which } \\
\text { is preserved in situ in the lower part } \\
\text { of the sample. Redeposition probably } \\
\text { under rainsplash into wet environment, } \\
\text { but recently highly bioturbated. The } \\
\text { lowermost part of the sample is composed } \\
\text { of in situ Eemian luvisol. }\end{array}$ & $\begin{array}{l}\text { Fig. } 1 \\
\text { Fig. 3D }\end{array}$ \\
\hline $\begin{array}{l}\text { Sample 5, depth } \\
\text { of } 307-310 \mathrm{~cm}\end{array}$ & $\begin{array}{l}\text { Angular blocky to chamber microstructure with granular and } \\
\text { chamber types of microstructure. Voids: cracks }(10 \%) \text { and } \\
\text { channels }(20 \%) \text { and compound packing voids }(50 \%) \text {. } \\
\mathrm{C} / \mathrm{F}(50 \mu \mathrm{m})=50: 70 \text {, clay loam. Orange matrix with cross } \\
\text { striated B fabric. Microcharcoal and decomposed organic } \\
\text { matter presented up to } 3 \% \text {. }\end{array}$ & & \\
\hline
\end{tabular}

is well developed in the background geology of the ditch and documented by sample 5 (Table 1 , sample 5).

\subsection{Case study Kolín}

The Kolín site, which was detected by a geophysical survey preceding the archaeological excavations, is situated extremely close to the Elbe River in the vicinity of one of its tributaries known as Pekelský stream (Figure 2). The largest rondel discovered during the excavations is composed of four concentric ditches: the outer one with a diameter of $210 \mathrm{~m}$, the inner one with a diameter of 140 m (Šumberová 2012). The construction of the outer ditch has never been completed. Two gates created by two radiating ditches were discovered: the north gate was investigated archaeologically, while the south gate was documented by a geophysical survey. On the basis of the archaeological material from the infilling, the rondel is dated to the Late Neolithic period (the later phase of Stroke-Ornamented Pottery culture).

The micromorphological samples document the formation processes of the main body of the infilling. Their description is shown in Table 2 and documented by Figures 2 and 3. The most significant process which took place in the formation of the studied horizons is the natural deposition under the slope documented by the presence of rip-up clasts (Figure 3E). The difference between the horizons depends on the type of material deposited into the ditch. The dark horizons are composed of the redeposited A horizon, only partly stabilised by vegetation (Table 2 , presented in all the studied samples). The stabilisation is documented by the presence of bioturbation (Figure $3 \mathrm{G}$ ) and the presence of calcified root cells (Figure $3 \mathrm{H}$ ). During the relatively quick deposition due to the disruption of the surface of the

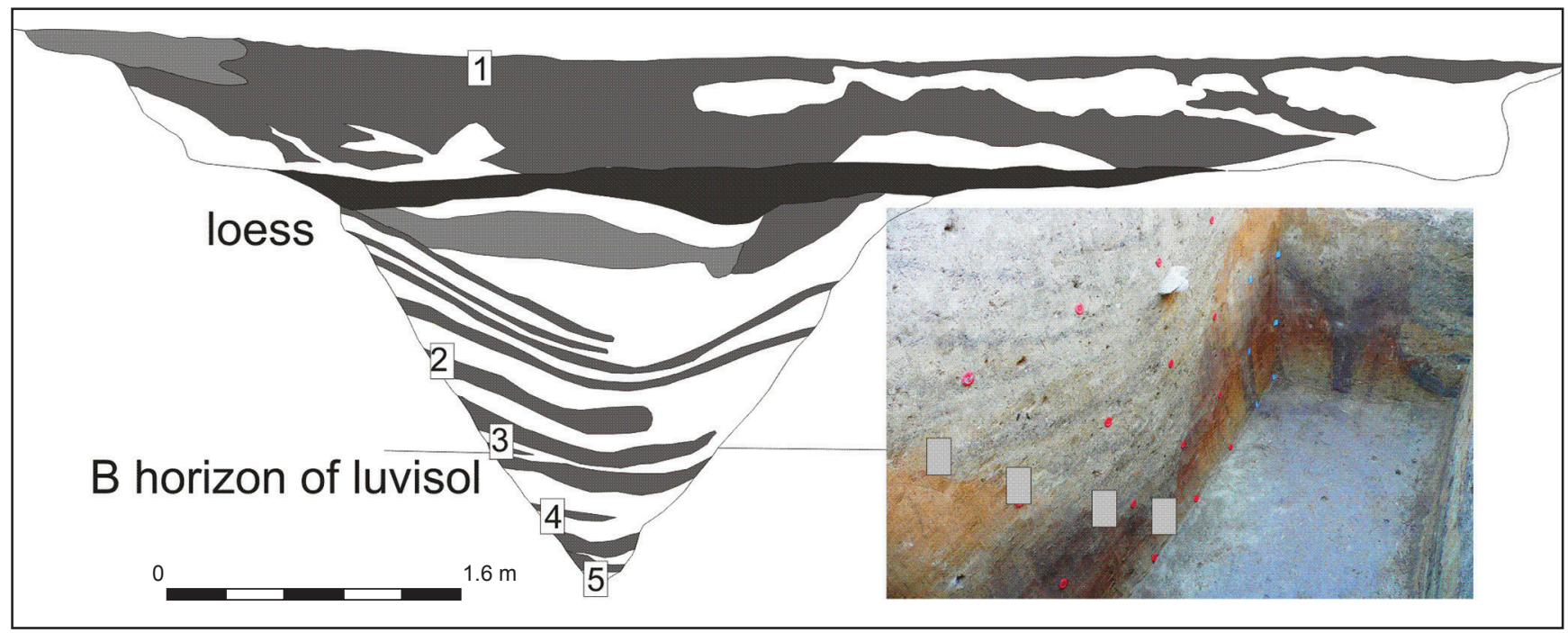

Figure 1. Schematic documentation of the section through the ditch of the Těštice-Kyjovice rondel. The grey marks document the positions of the micromorphological samples. 
Table 2. Micromorphological description and interpretations of samples from the 3B section of the Kolín rondel.

\begin{tabular}{ll}
\hline \multicolumn{1}{c}{ Sample/horizon } & \multicolumn{1}{c}{ Description } \\
\hline $\begin{array}{l}\text { Sample M1, lighter } \\
\text { horizons, depth of }\end{array}$ & $\begin{array}{l}\text { Complex microstructure. Voids: chanels }(20 \%) \text { and compound } \\
\text { packing voids }(30 \%) . \mathrm{C} / \mathrm{F}(50 \mu \mathrm{m})=30: 70, \text { loam. Orange brown }\end{array}$ \\
$86-88,91-96 \mathrm{~cm}$ & $\begin{array}{l}\text { matrix, B fabric granostriated. Microcharcoal }(5 \%) \text {, decomposed } \\
\text { dark }(5 \%) \text { and light }(5 \%) \text { organic matter and partly decomposed } \\
\text { organic matter }(1 \%) . \text { Phytoliths presented but rare, high } \\
\text { bioturbation, carbonate accumulations in the form of infillings with } \\
\text { root cell pseudomorphoses. }\end{array}$
\end{tabular}

Sample M2, darker Channel microstructure composed of subrounded clasts of light and horizons, depth of dark matrix. Voids: channels, mainly within dark clasts $(20 \%)$ and $88-91 \mathrm{~cm}$ compound packing voids $(50 \%) . \mathrm{C} / \mathrm{F}(50 \mu \mathrm{m})=30: 70$, loam. Brown to dark brown matrix with granostriated $\mathrm{B}$ fabric. Microcharcoal presented but rare (1\%), decomposed dark (10-15\%) and light $(5 \%)$ organic matter and partly decomposed organic matter $(1 \%)$. Phytoliths presented but rare, carbonate accumulations in the form of coatings, hypocoatings and infillings. Accumulations of calcium carbonate presented in the form of coating and fine grained concentrations and root infillings within the matrix. Root cell pseudomorphoses and redeposited calcium carbonated accumulations detected.

Sample M2, darker Analogous to M2, darker horizon horizon, depth of 96-101 cm

Sample M2, lighter Massive to channel microstructure with the intercalations of 0.4 $\begin{array}{ll}\text { horizon, depth of } & \text { mm representing bioturbated soil crusts with positive gradation. } \\ 101-106 \mathrm{~cm} & \text { Voids: channels }(20 \%) \text { and compound packing voids }(30 \%) \text {. }\end{array}$ $101-106 \mathrm{~cm}$ $\mathrm{C} / \mathrm{F}(50 \mu \mathrm{m})=30: 70$, loam. Orange brown matrix, B fabric granostriated. Microcharcoal (5\%), decomposed dark (5\%) and light $(5 \%)$ organic matter and partly decomposed organic matter (1\%). Phytoliths presented but rare, high bioturbation, carbonate accumulations in the form of infillings with root cell pseudomorphoses. Thin intercalation are of a clayley loam grain size with no voids. The matrix of intercalations is dark brown $\mathrm{C} / \mathrm{F}(10 \mu \mathrm{m})=50: 50$ with B crystalic B fabric.
Interpretation

Layers developed due to the deposition under the slope. The difference between them depends on the type of material deposited into the ditch. Dark horizons are composed of redeposited A horizon, just partly stabilised by vegetation. During the relatively rapid deposition due to the disruption of the surface of the source area loess material from the walls was also partly eroded, the roundness of the soil clasts is due to the gravitation. The light material represents the product of degradation of loess walls or earthwork near the ditch due to the rainsplash recently influenced by seasonal frost activity and producing platy microstructure.

Phases of slumping and sheet wash erosion of ditch walls, producing lighter and less bioturbated material are from time to time interrupted by more intensive rainwash phases. Water is accumulated within the ditch depression and sedimentation from suspension begins to take place. After sedimentation, posdepositional processes such as drying and bioturbation degrade these thin layers.
Photo documentation

Fig. 2

Fig. 3D, G
Fig. 2

Fig. 3F

Analogous to M2, lighter horizon

Sample M3, depth Analogous to M2, lighter horizon of $110-120 \mathrm{~cm}$

Sample M4, depth Channel to granular, partly platy microstructure. Voids: channels, of $122-124$, $126-127 \mathrm{~cm}$ mainly within dark clasts $(20 \%)$ and compound packing voids $(50 \%) . \mathrm{C} / \mathrm{F}(50 \mu \mathrm{m})=30: 70$, loam. Brown matrix with crystalic B fabric. Microcharcoal presented but rare (1\%), decomposed dark $(10-15 \%)$ and light $(5 \%)$ organic matter and partly decomposed organic matter $(1 \%)$. Phytoliths presented but rare, carbonate accumulations in the form of coatings, hypocoatings and infillings. Bioturbation presented and also excremental pellets of microfauna. Accumulations of calcium carbonate presented in the the form of coating and fine grained concentrations within the matrix. Redeposited calcium carbonated accumulations detected.
Sample M4, depth of 124-126, $127-130 \mathrm{~cm}$
Channel to granular microstructure, voids: channels (20\%), compound packing voids $(50 \%) . \mathrm{C} / \mathrm{F}(50 \mu \mathrm{m})=30: 70$, loam. Matrix light brown to grey, composed of carbonates, part of matrix (20\%) is brownish. Crystalic B fabric. Microcharcoal presented but rare (1\%), decomposed dark (10-15\%) and light (5\%) organic matter and partly decomposed organic matter (1\%). Phytoliths presented but rare, carbonate accumulations in the form of coatings, hypocoatings and infillings. Bioturbation observed with microfauna excremental pellets. Rarely angular clasts of dark brown matrix with decomposed organic matter documented. Left part of sample is composed of loess representing the geological background of the locality.
The light material represents the product of degradation of loess walls or earthwork near the ditch due to the rainsplash recently influenced by seasonal frost activity and producing platy microstructure.

Highly bioturbated horizon of redeposited soil recently covered by vegetation. The rarely presented angular clasts come from $\mathrm{A}$ horizon of black earth like soil. No standing water environment detected.

Fig. 2 Fig. $3 \mathrm{G}, \mathrm{B}$

Fig. 2

Fig. 3C 
Table 2. Micromorphological description and interpretations of samples from the 3B section of the Kolín rondel (continue).

\begin{tabular}{lcc}
\hline Sample/horizon & Description & Interpretation \\
& & documentation \\
\hline
\end{tabular}

Sample M5, depth Analogous to M2, lighter horizon of $184-187 \mathrm{~cm}$

Sample M5, depth Analogous to M4, depth of 124-126, 127-130 cm. of $187-189 \mathrm{~cm}$

Sample M5, depth Granular microstructure with preferred orientation of clasts. oids: of $189-194 \mathrm{~cm}$

channels (5\%), compound packing voids $(60 \%)$.
$\mathrm{C} / \mathrm{F}(100 \mu \mathrm{m})=80: 20$, sandy loam. Different grain size distribution is the reason for the laminae. These silty laminae are of two types. The lighter are primarily composed of rounded and subrounded quartz clasts $(100 \mu \mathrm{m})$, while the dark ones are composed of subrounded clasts of humus rich matrix (100-200 $\mu \mathrm{m})$ and decomposed organic matter. The matrix of darker layers is dark brown. Crystalic B fabric. Microcharcoal presented but rare (1\%), decomposed dark (10-15\%) and light (5\%) organic matter and partly decomposed organic matter $(1 \%)$.

Sample M6, depth Analogous to M2, lighter horizon of $216-218 \mathrm{~cm}$

Sample M6, depth The horizon is composed of subangular clasts of dark brown of $218-224 \mathrm{~cm}$ matrix with decomposed organic matter. Channel to chamber microstructure, voids: channels (20\%), compound packing voids $(30 \%)$ and chambers $(10 \%) . \mathrm{C} / \mathrm{F}(50 \mu \mathrm{m})=30: 70$, loam. Matrix dark brown, part of the matrix (20\%) is yellowish. Crystalic B fabric. Microcharcoal presented but rare (1\%), decomposed dark (40\%) and light $(10 \%)$ organic matter and partly decomposed organic matter (5\%). Phytoliths presented but rare, carbonate accumulations in the form of coatings, hypocoatings, infillings. Bioturbation observed with microfauna excremental pellets.

Sample M7, depth Massive to channel microstructure. Voids: channels (20\%) and of $224-226 \mathrm{~cm}$ compound packing voids $(30 \%) . \mathrm{C} / \mathrm{F}(50 \mu \mathrm{m})=30: 70$, loam. Orange brown matrix, B fabric granostriated. Microcharcoal (5\%), decomposed dark $(5 \%)$ and light $(5 \%)$ organic matter and partly decomposed organic matter (1\%). Phytoliths presented but rare, high bioturbation, carbonate accumulations in the form of infillings with root cell pseudomorphoses. Thin intercalation are of clayley loam grain size with no voids. The matrix of intercalations is dark brown $\mathrm{C} / \mathrm{F}(10 \mu \mathrm{m})=50: 50$ with $\mathrm{B}$ fabric crystallic.
Analogous to M2, lighter horizon

Analogous to M4, depth of

$124-126,127-130 \mathrm{~cm}$.

These horizons are a result of the heavy rainstorms when rill erosion

Fig. 2 occurred on fallow arable land, or

Fig. 3E on arable land only partly covered by crops.
Analogous to M2, lighter horizon

Phases of slumping and sheet wash erosion of ditch walls with a high percentage of redeposited soil and

Fig. 2 buried organic matter. $\begin{array}{lc}\text { Phases of slumping and sheet wash } & \text { Fig. } 2 \\ \text { erosion of ditch walls, producing } & \text { Fig. } 3 \mathrm{H}\end{array}$ erosion of ditch walls, prod
lighter and less bioturbated material 


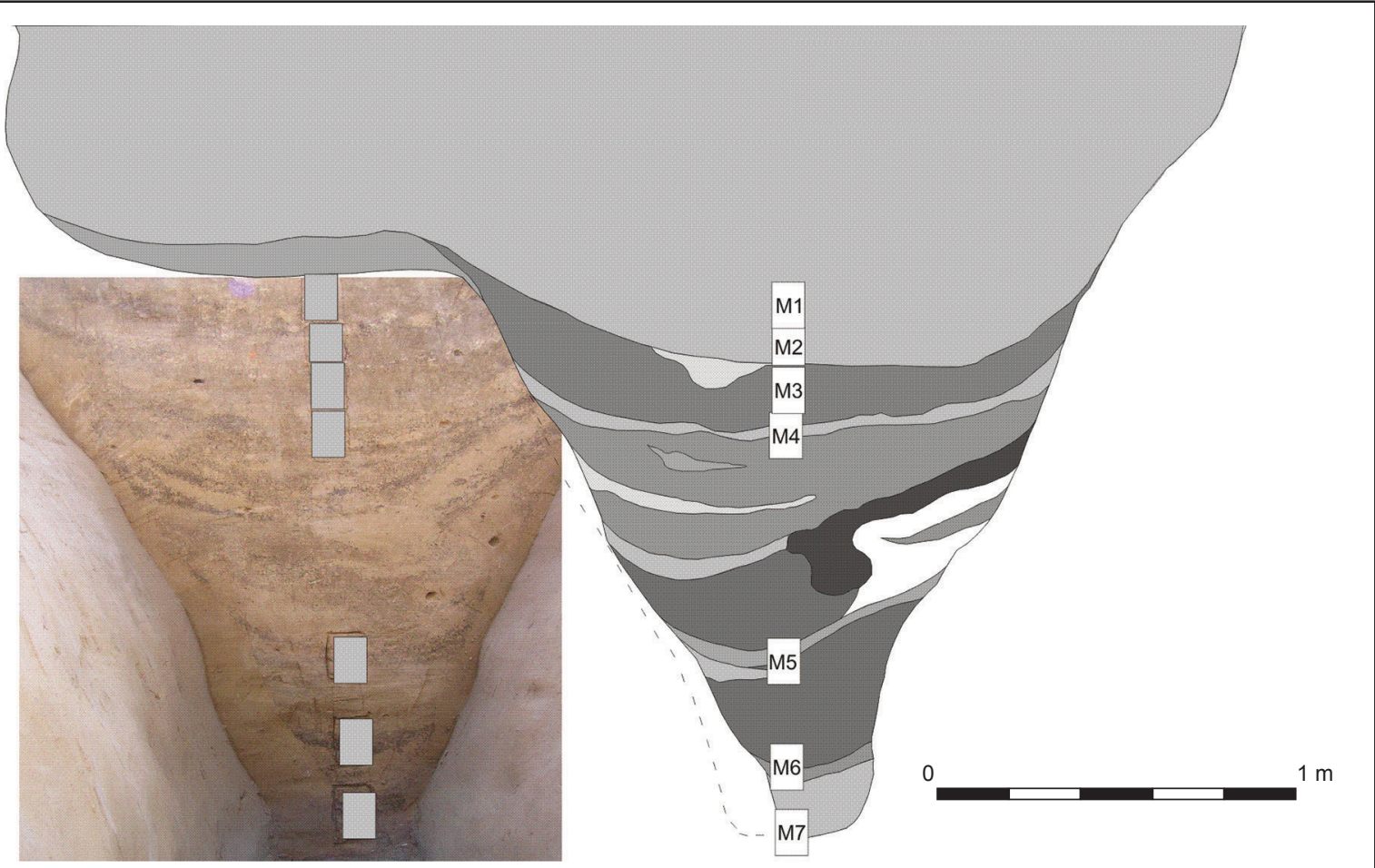

Figure 2. Schematic documentation of the section through the third ditch of Kolín rondel no. 1. The grey marks document the positions of the micromorphological samples.

\section{Interpretation and discussion}

\subsection{Classification of the depositional processes}

The question of a suitable manner of studying rondels has been updated in connection with a boom in the discovery of rondels throughout Central Europe. As the potential of classic archaeological methods has mostly been exhausted, they rarely produce any important new information. The time has therefore arrived to utilize procedures which provide a new view of the given issue. One of the possible methodological tool is micromorphology (Davidson et al. 1992), but up to the present, to our knowledge, various micromorphological criteria for recognizing the natural or anthropogenic processes which take place during the infilling history of archaeological objects, particularly rondels, have not been categorised and systematically classified. Loishandl-Weisz and Peticzka (2011) have tried to explain, on the Steinabrunn locality, the processes which might take place during the infilling of neolithic rondels. Recently, only Karkanas and Goldberg (2013) have tried to summarize the microscopic features produced by major natural depositional processes acting within a cave environment. These processes are primarily associated with changes in the geomorphic system, the climate and the presence of man, thus the classification of both cave and archaeological objects might be extremely similar.

According to Davidson et al. (1992) three main categories of features visible within archaeological objects can be discerned: those related to the source of the sediment, those which reveal something about the soil formation processes and those that are produced or modified by man, whether deliberately or accidentally. Analyses of soils and sediments can also provide data on the long-term processes of deposition and erosion (Renfrew, Bahn 2000, 235-237). An analysis of ditch sediment from the Těšetice Kyjovice rondel and from the Kolín rondel revealed that the structural and textural elements of the redeposited layers were continually repeated in a certain way, making it possible to deduce the following facts from the micromorphological study of these infillings: the phase of frequent bioturbation, the phase of quick redeposition, the phase of standing water, the minimal amount of microartefacts and charcoals, the intensification of sheet erosion, the phase of standing water and the occurrence of horizontal pores connected with freezing.

\subsubsection{The phases of quick and slow redeposition}

The slope processes play a key role in forming the main mass and particularly the lower part of the rondel ditches. A typical microstructure documenting this process is presented in Figures 3E and 3D. Slope deposits are generally sediments found on slopes or at the base or the foot of slopes which, according to Mücher et al. (2010), result from two main groups of processes: (a) colluvial deposits including slope wash, hill wash or rain wash including soil erosion on agricultural land and (b) mass wasting including solifluction deposits, landslides and debris flow deposits. Both of those processes are possible in the case of rondel ditches. The macromorphological characteristics of the various types 


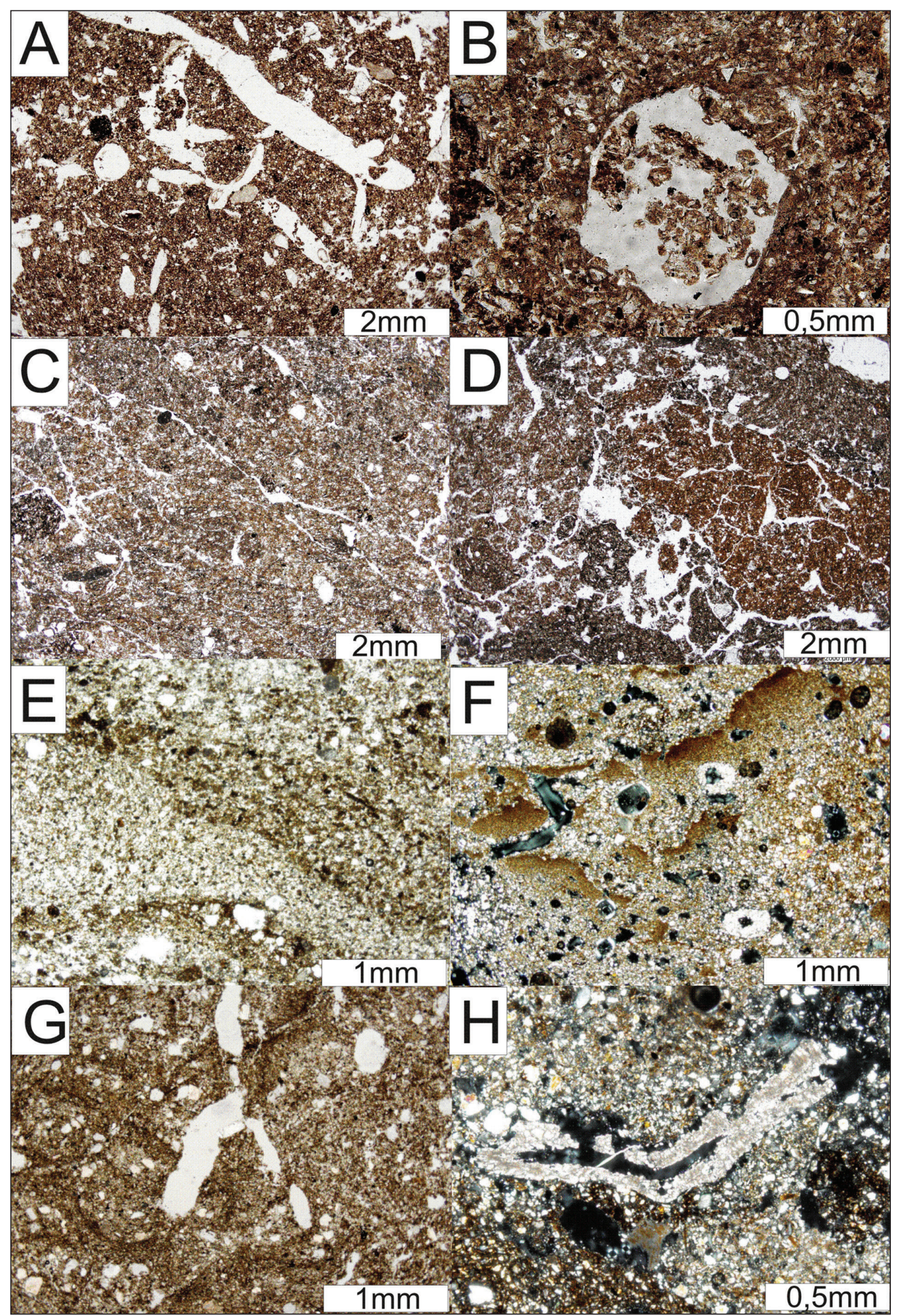

Figure 3. Microphotodocumentation of typical features detected in thin sections within rondel infillings of the Těšetice-Kyjovice (A-D) and the 3B ditch of Rondel in Kolín (E-H). A - highly bioturbated fertilised horizon of redeposited soil with a typical channel microstructure (PPL); B - excrements of microfauna (PPL); C - platy to lenticular microstructure of frost affected soil (PPL); D - subangular clasts of loess and soil redeposited rainsplash erosion (PPL); E - rip-up clasts of soil and coarse quartz as a product of high energy deposition (PPL); F - graded laminae as a product of sorting in standing water (XPL); $\mathrm{G}$ - bioturbation presented by the internal orientation of matrix, channel microstructure (PPL); $\mathrm{H}$ - calcified root cells as an infilling of channels (XPL); PPL - plane polarised light; XPL - cross polarised light. 
of slope deposits are quite well documented (recently reviewed by Hiscott 2003) while the micromorphological characteristics of slope sediments are usually primarily concerned with solifluction deposits (reviewed by Van VlietLanoë 2010). Bertran and Texier (1999) also published a paper focused on a detailed description of facies and microfacies of slope deposits. A review of the micromorphological characterisation of slope sediments was carried out by Mücher et al. (2010).

Mücher (1974) described the origin of laminated colluvium developed in loess material. As the loess material composes the background of the studied rondel, features of this type are characteristic and correspond to the described phenomenon. In the loess, the laminated colluvium is composed of individual layers predominantly 1-2 mm thick, homogenous in composition and more or less parallel to the soil surface. Field observations revealed that these deposits are formed during heavy rainstorms when rill erosion occurred on fallow arable land, or on arable land only partly covered by crops, which fail to protect the soil from rain splash impact (Mücher 1974). The construction of rondel ditches also probably led to the removal of vegetation and the beginning of erosion. Similar sedimentary features as Mücher (1974) have been described by Bertran and Texier (1999) and interpreted as overland flow, i.e. a process where the main factors in play are low to intermediate sediment concentration and interstitial fluid, which could be water or water plus fine particles. Water is in all probability the primary factor which took place during the sediment redeposition into the ditch infilling, although for example aeolian or frost processes cannot be excluded either. Overland flow deposits are usually moderately sorted with a marked spatial grain-size variation. The clast fabric ranges from random to weakly oriented (Bertran et al. 1997). The deposits typically demonstrate laminated lenses interstratified with massive deposits which is in fact an example of the laminated part of the body infilling of the studied rondels (samples 2-5 in case of the Těšetice-Kyjovice rondel, see Table 1 and Figure 3). The lenses with obvious lamination and evidence of sorting (Figure 3E) represent areas where vertical or lateral accretion due to dilute flows is rapid (Bertran, Texier 1999). Massive yellow or dark layers might also have originated by slumping. According to Karkanas and Goldberg (2013), the slumping deposits have a sharp erosional contact with the underlying substrate and a number of the aggregates attain a more concave configuration toward the direction of the flow. These sediments are in the case of the rondel ditch infillings easily interpretable from a macroscopic point of view, as they are not usually composed of a continuous layer but merely tongue-like accumulations. Massive deposits recorded in the study sections represent areas of hyperconcentrated flow accumulation or areas where accretion is slow and post-depositional perturbations such as splash, bioturbation, freezing and thawing are strong (Bertran, Texier 1999; see sample 3, lighter horizon - Table 1). Karkanas and Golberg (2013) have also divided types of slow deposits depending on the degree of energy within the cave environment. Lower- energy flows produce less sorted and more crudely bedded microstructures which correspond to the more massive yellow laminae of studied rondel ditch infillings.

The laminae of the rondel ditch infillings are composed at times of rounded aggregates with different degrees of sorting. This is for example the darker layers within samples 2 and 4 (Table 1) in case of the Těšetice-Kyjovice rondel. Mücher et al. (1981) interpreted the appearance of rounded aggregates as a result of disruption by running water of subsoil horizons, primarily Bt horizons which are relatively stable during transport in water. Laboratory experiments on loess reveal that sediment influenced by turbulent rainwash form a poorly layered colluvial deposit with poorly sorted individual laminae (Mücher, De Ploey 1977). Similar features were described in the lower part of the Kolín rondel ditch infilling (Figure 3E). Karkanas and Goldberg (2013) described this type of deposits as a common one in a cave environment. Angular to subangular, clay clast layers alternating with finely laminated clays have been in their view interpreted as a result of episodic high-flow events. These kinds of features were only rarely observed within the studied sections as mentioned above. In contrast, a lower energy process resulting, according to Karkanas and Goldberg (2013), in microscopically stratified deposits with angular clasts revealing an inclined preferred orientation to the slope and interpreted as a flow of liquefied sediments (debris flow) are quite common within the studied rondel sections and are primarily located at the bottom of the studied rondel ditch infillings. They are well developed in the case of the Těšetice-Kyjovice locality where part of the deposited material is the $\mathrm{Bt}$ horizon of the Eemian Bt horizon of luvisol (Table 1, Figure 3)

\subsubsection{The phases of standing water}

Soil crusts were recorded within the infilling of the studied rondel ditches. These graded facies, usually of a thickness of $0.3-4 \mathrm{~mm}$, were commonly disrupted, which might be due to the bioturbation or drying, swelling processes after the sedimentation. They were quite common primarily in the case of the Kolín site. Graded facies consisting of repetitive fining upward sequences of sand, silt and clay, usually less than a few millimetres thick, mainly observed in the cave environment (Goldberg, Macphail 2003) were also observed within the sedimentary fill of Neolithic rondels. In the case of both cave sediments and rondels, individual laminae are extremely well sorted with generally sharp contacts (Karkanas, Goldberg 2013). Such repetitive events of differential sediment setting imply the presence of static water into which pulsed sediments are washed (Shunk et al. 2006). Another possible explanation is occasional standing water body due to rainstorms. In such an environment, soil crusts similar to the graded cave facies may come about.

\subsubsection{Freezing phases}

The presence of horizontal pores was occasionally observed in the studied sections. These features are quite rare but were presented in lighter as well as in darker horizons and might 
be interpreted as phases of freezing (Van Vliet-Lanoë 2010), which might not be necessarily connected with climate change. Uncovered soil is more accessible to frost action and such features might originate during one season. These phases were detected in both the studied rondel infillings (see Table 1, sample 3 and Table 2, sample 4).

\subsubsection{The phases of frequent bioturbation}

Bioturbation of sediment is a postsedimentary feature reflecting in situ biological activity. Macroscopic burrows produced by rodents can range from 8 to $10 \mathrm{~cm}$ tubular shapes for small animals up to several dm across in the case of badgers or porcupines (Karkanas, Goldberg 2013). Such features, visible with the naked eye, occurred in the case of the studied ditch infillings of rondel structures more or less just at the uppermost situated destruction layer, although they were clearly visible micromorphologicaly (Figures 3A, 3B, $3 \mathrm{G}, 3 \mathrm{H})$. Invertebrates, such as snails, produce centimetresize burrows and tubes, whereas insects (wasps and ants) produce smaller burrows, typically in the milimeter-size range (Karkanas, Goldberg 2013). Burrows are usually filled with softer material than the surrounding matrix and have loose, heterogeneous and aggregated fabric (Goldberg, Bar-Yosef 1998). In the case of the studied rondels, the bioturbation is presented continually over all the section, although some of the layers have visibly higher bioturbation intensity. These layers are usually also rich in fine-grained organic matter. All the microorganisms feed in essence on soil organic matter (Brussaard, Juma 1996), thus their increased activity in these layers is quite obvious. Microfauna rarely have a direct impact on the soil structure since its presence attracts larger organisms which may influence the type of soil structure (Kooistra et al. 1989). The bioturbation features identified within the studied infillings of the rondel structures originated in situ, i.e. the soil material had to contain active soil fauna after the redeposition. The presence of an active soil fauna population is often provided in relationship with the formation of the soil horizon (Davidson et al. 2002). Entire soil horizons can be bioturbated or completely depleted in fine grained particles (Kooistra et al. 1990; Schaefer 2001). This means, in contrast, that the infilling of rondel ditches as a whole was quite slow and the bioturbation by plants and mesofauna was more or less continuous. The bottom of the ditch is partly restricted in terms of sunshine, although on the other hand such depressions offer increased humidity with material redeposited already rich in decomposed organic matter. These factors played an important role in the origin of the bioturbation features.

\subsubsection{Phases of carbonate accumulations}

The presence of carbonated coatings, hypocoatings, infillings and accumulations is quite common in loess material since calcium carbonate is easily moved by percolating water in connection with growing vegetation. Common root related features (Durand et al. 2010) occur all over the studied section. Due to their high solubility, carbonates may dissolve from the horizons in which they originally accumulated as a reaction to changes in climate or local conditions towards a higher humidity. This is in particular the example of the Těšetice-Kyjovice rondel ditch infilling. Carbonate accumulations were misunderstood there by Zeman and Havlíček (1988) with trampled horizons.

\subsection{Depositional geomorphology and infilling of ditches}

The ditches of Neolithic rondels usually have a sharp profile. The width of the ditches varies between 1.5-14 metres with their depth usually being between 1 to 4.5 metres (Řídký et al. 2012) which means that during the construction a high amount of material had been excavated. An estimation of this amount is quite tricky. This kind of material was probably redeposited nearby in the form of earthwork (Kovárník, Mangel 2013; Lenneis 1977; Modderman 1983; NěmejcováPavúková 1986; Neugebauer 1986; Oliva 2004; Válek et al. in print) and recently during the erosion phases redeposited back into the inner parts of the ditch.

The natural way of redeposition in the case of rondel ditches was described by Broes and Bosquet (2007). They carried out experimental work on the method of sharp profile ditch infilling with the earthwork close to the ditch. In their view, no intensive sedimentation was observed seven months after the abandonment of the ditch. The erosion of the walls caused the infilling of the bottom of the ditch up to $50 \mathrm{~cm}$. As the vegetation cover grows the erosion slows down. During the $3^{\text {rd }}$ week of the experiment the plants began to settle the earthwork and the uppermost parts of the walls. Three weeks later, two thirds of the earthworks and ditch were covered by the vegetation and by the $9^{\text {th }}$ week of the experiment rich vegetation was covering both the earthwork and ditch including its walls. The bottom of the ditch was re-covered occasionally by slumping of the material from the walls which produced the repeated sedimentation of the dark and yellow layers. Although Broes and Bosquet (2007) unfortunately did not specify the role of the earthworks during these taphonomic processes, it is apparent that the first stage of the infilling was quite rapid. Later the sedimentation and erosion reached a kind of equilibrium.

There are additional authors suggesting that the earthworks were not present and that the material was merely redeposited on the surface around the rondel (Trnka 1986; Podborský 1988), although the presence of exotic material (stones, sands, mudbricks) in certain cases mainly points to the first hypothesis. If the earthworks were not present, then there is a question as to where the lithologically varied material transported into the ditch comes from. Part of it might have eroded from the walls of the ditch (loess material) and from the surrounding area (soil material), although the lack of a wide source area for the soil material suggests in fact the presence of earthwork which would produce such material. Approximately the lower two thirds of the infilling were redeposited into the ditch naturally mainly via slope processes, as is visible from the textural features and micromorphological descriptions. The upper part of the infilling is quite homogenous and highly bioturbated with no textural or microstructural features suggesting a natural 
redeposition. In addition, the slope of the ditch at that time became milder and therefore a natural redeposition probably did not take place. Similar features dated to the same period are known which were not naturally infilled because the landscape was not agriculturally used (Oliva 2004). The infilling of this part of the profile is probably connected with intentional activity bound up with agriculture, with a direct effort at flattening the terrain. The soil material transported into the ditch was recently bioturbated, although in light of its quantity it originally comes from the A horizon of some soil previously developed over the long time period.

\section{Conclusions}

The given results lead to the following interpretations: the rondel ditch infillings studied in Těšetice-Kyjovice and in the case of Kolín consist of two main types of infillings. The laminated part of the body composes approximately two thirds of the lower infilling while the generally massive material composes the uppermost part of the ditch infilling. There are macroscopically and micromorphologically visible differences in these two types of facies. While the massive infill in the uppermost part of the infilling was deposited by man, the lower laminated part of the infilling is primarily the result of geomorphological and climatic conditions. The colluvial processes also prevail and different phases of sedimentation might be observed within both studied localities. There was in all probability a rampart near the ditch and this was the source of the material by which the ditch was refilled naturally. The facies in the ditch infilling reflect the phases and stabilization of this rampart. The studied part of the ditch was probably not cleaned; the infilling occurred relatively quickly at first and then slowed due to the stabilization of the landscape and the disappearance of the source of material.

\section{Acknowledgements}

The contribution was funded by Masaryk University (MUNI/21/VAL/2011) and by the Grant Agency of the Czech Republic (project no. P405/11/1590 - Neolithic rondels from the perspective of micromorphologic and formative analysis).

\section{References}

BARTELS, R., BRESTRICH, W., DE VRIES, P., STÄUBLE, H. 2003 Ein neolitisches Siedlungsareal mit Kreisgrabenanlagen bei DresdenNickern. Eine Übersicht. Arbeits- und Forschungsberichte zur Sächsichen Bodendenkmalpflege 45, 97-133.

BERTRAN, P., TEXIER, J. P. 1999: Facies and microfacies of slope deposits. Catena 35, 99-121.

BERTRAN, P., HÉTU, B., TEXIER, J. P., VAN STEIJN, H. 1997: Fabric characteristic of subaerial slope deposits. Sedimentology, 44, 1-16.

BROES, F., BOSQUET, D. 2007: Fabrication d'outils de terrassier et creusement des fossés rubanés: de la théorie a la practic. Notae
Praehistoricae 27, 131-149.

BRUSSAARD, L., JUMA, N. G. 1996: Organisms and humus in soils. In Piccolo A. (Ed.): Humic substances in Terrestrial ecosystems. Elseiver, Amsterdam, 329-359.

BULlOCK, P., FEDOROFF, N., JONGERIUS, A., STOOPS, G., TURSINA, T. 1985: Handbook for soil thin section description. Waine Research Publications, Wolverhamton.

DAIM, F., NEUBAUER, W. 2005: „Zeitreise Heldenberg. Geheimnisvolle Kreisgräben“. Katalog zur Niederösterreichischen Landesausstellung 2005. Verlag Berger, Horn - Wien.

DAVIDSON, D. A., CARTER, S. P., QUINE, T. A. 1992: An evaluation of micromorphology as an aid to archaeological interpretation. Geoarchaeology 7/1, 55-65.

DAVIDSON, D. A., BRUNEAU, P. M. C., GRIEVE, I. C., YOUNG, I. M. 2002: Impacts of fauna on an upland grassland soil as determined by micromorphological analysis. Applied Soil Ecology 20, 133-143.

DURAND, N., MONGER, H. C., CANTI, M. G. 2010: Calcium Carbonate features. In.: Stoops, G., Marcelino, V., Mees, F. (Eds.): Interpretation of Micromorphological features of Soils and Regoliths. Elseiver, Amsterodam, 149-194.

GOLDBERG, P., BAR-YOSEF, O. 1998: Site formation processes in Kebara and Hyonim caves and their significance in Levantine prehistoric caves. In: Akazawa, E. A. (Ed.): Neanderthals and Modern Humans in Westen Asia. Pienum, New York, 107-125.

HISCOTT, R. N. 2003: Slope sediments. In: Middleton, G. (Ed.): Encyclopedia of sediments and sedimentary rocks. Cluwer Academic publishers, Dordrecht, 668-672.

KARKANAS, P., GOLDBERG, P. 2013: Micromorphology of Cave Sediments. In: Shroder, J. F., Frumkin, A. (Eds.): Treatise on Geomorphology, Vol. 6, Karst Geomorphology. Academic Press, San Diego, 286-297.

KOOISTRA, M. J., LEBBINK, G., BRUSSAARD, L. 1989: The Dutch programme on soil ecology of arable farming systems. II. Geogenesis, agricultural history, field site characteristics and present farming systems at the Lovinkhoeve experimental farm. Agriculture, Ecosystems \& Environments 27, 361-387.

KOOISTRA, M. J., JUO, A. S., SCHOONDERBEEK, D. 1990: Soil degradation in cultivated Alfisols under different management systems in Southern Nigeria. In Douglas, L. A. (Ed.): Soil micromorphology: A basic and Applied Science. Development in soil science. Volume 19, Elseiver Amsterdam, 61-68.

KOVÁRNÍK, J., MANGEL, T. 2013: Rondel s valy u Třebovětic. Poznámka ke konstrukčním znakům mladoneolitických rondelů. In: Cheben, I., Soják, M. (Eds.): Otázky neolitu a eneolitu našich krajín 2010. Nitra, 133-152.

LENNEIS, E. 1977: Siedlungsfunde aus Poigen und Frauenhofen bei Horn. Horn - Wien.

LOISHANDL-WEISZ, H., PETICZKA, R. 2011: Mechanismus zaplňování hrotitého prŕíkopu mladoneolitického rondelu na lokalitě Steinabrunn, Dolní Rakousko. Archaeologia Austriaca 91/2007, 141-162.

MODDERMAN, P. J. R. 1983: Einige Gedanken zur Geutung der mittelneolitischen Grabenanlagen. Mitteilungen der Österreichischen Arbeitsgemeinschaft für Ur- und Frühgeschichte 33-34, 347-350.

MÜCHER, H. J. 1974: Micromorphology of slope deposits: the necessity of a classification. In Rutherford, G. K. (Ed.): Soil Microscopy. The Limestone Press, Kingston, Ontario, 553-566.

MÜCHER H. J., DE PLOEY, J. 1977: Experimental and micromorphological investigation of erosion and redeposition of loess by water. Earth Surface Processes and Landforms 2, 117-124.

MÜCHER, H. J., DE PLOEY, J., SAVAT, J. 1981: Response of loess materials to simulated translocation by water: micromorphological observations. Earth Surface Processes and Landforms 6, 331-336.

MÜCHER, H. J., VAN STEIJN, H., KWAAD, F. 2010: Colluvial and Mass Wasting Deposits. In: Stoops, G., Marcelino, V., Mees, F. (Eds.): Interpretation of Micromorphological features of Soils and Regoliths. Elsevier, Amsterodam, 37-48.

NEUGEBAUER, W. 1986: Neuere Forschungsergebnisse auf dem Gebiet der Hallstattkultur in Nordösterreich. Archäologie Alpen Adria 1, 85-107.

NĚMEJCOVÁ-PAVÚKOVÁ, V. 1986: Siedlung und Kreisgrabenanlagen der Lengyel-Kultur in Svodín (Südslovakei). In: Chropovský, B., Friesinger, H. (Eds.): Internationales Symposium über die LengyelKultur. Nitra - Wien, 177-183. 
OLIVA, M. 2004: Flint mining, rondels, hillforts... Symbolic works or too much free time? Archeologické rozhledy 56, 499-531.

PAVLŮ, I. 1982: Die Neolitische Kreisgrabenanlagen in Böhmen. Archeologické rozhledy 34, 176-189.

PODBORSKÝ, V. 1988: Těšetice-Kyjovice 4. Rondel osady lidu s moravskou malovanou keramikou. Brno.

PODBORSKÝ, V. 1999: Těšetice-Kyjovice I, okr. Znojmo. In: Podborský, V. (Ed.): Pravěká sociokultovní architektura na Moravě. Brno, 115-132.

RENFREW, C., BAHN, P. 2000: Archaeology. Theories, Method and Practice. Thames and Hudson, London.

ŘÍDKÝ, J. 2011: Rondely a struktura sidelních areálů v mladoneolitickém obdobi. Dissertationes Archaeologicae Brunenses/Pragensesque 10. Praha - Brno.

ŘIIKÝ, J., KVĚTINA, P., PŮlPÁN, M., KOVAČIKOVÁ, L., STOLZ, D., BREJCHA, R., ŠREJNOVÁ, B., ŠREJN, V. 2012: Analýza a interpretace nálezů z př́kopu neolitického rondelu ve Vchynicích (okr. Litoměřice). Archeologické rozhledy 64, 628-694.

SCHAEFER, C. E. G. R. 2001: Brazilian latosols and their B horizon microstructure as long-term biotic constructs. Australian Journal of Soil Research 39, 909-926.

SHUNK, A. J., DRIESE, S. G., CLARK, M. G. 2006: Latest Miocene to earliest Pliocene sedimentation and climate record derived from paleosinkhole fill deposits, Gray fossil site, northeastern Tenessee, USA. Paleogeography, Paleoclimatology, Paleoecology 231, 265-278.

STOOPS, G. 2003: Guidelines for analyses and descriptions of soil and regolith thin sections. Science Society of America, Madison.

ŠUMBEROVÁ, R. 2012: Neolitické rondely a hroby v trase obchvatu silnice I/38 mimo Kolín. Předběžná informace o průběhu výzkumu v roce 2008. Sbornik praci filozofické fakulty brněnské univerzity M 17, 47-64.
TRNKA, G. 1986: Ergebnisse zur Untersuchungen der Kreisgrabenanlage von Kamegg und Strassertale, Niederösterreich. In. Chropovský, B., Friesinger, H. (Eds.): Internationales Symposium über die LengyelKultur. Nitra - Wien, 289-295.

TRNKA, G. 1991: Studien zu mittelneolithischen Kreisgrabenanlagen. Mitteilungen der Prähistorischen Kommission der Österreichischen Akademie der Wissenschanften 26. Verlag der Österreichischen Akademie der Wissenschaften, Wien.

VAN VLIET-LANOË, B. 2010: Frost action. In: Stoops, G., Marcelino, V., Mees F. (Eds.): Interpretation of Micromorphological features of Soils and Regoliths. Elsevier, Amsterodam, 81-108.

VÁLEK, D., KAZDOVÁ, E., KOVÁŘ, J. J. 2013: Cíle a průběh revizního výzkumu př́kopu neolitického rondelu v Těšeticích-Kyjovicích (okr. Znojmo). Sborník praci filozofické fakulty brněnské university M 18, in print.

VÁLEK, D., LISÁ, L., DOLÁKOVÁ, N., UHLÍŘOVÁ, H., BAJER, A., in print: New evidence of origin and artefactual information value of the rondel ditch infilling in Těšetice-Kyjovice (Znojmo district). Acta Mus. Moraviae, sci. soc.

VOKOLEK, V. 1963: Třebovětice, okr. Jičín. MS. Excavation report. Deposited: Archiv Muzea východních Čech, Hradec Králové, Czech Republic.

ZEMAN, A., HAVLÍČEK, P. 1988: Geologická expertíza př́ikopu. In: Podborský, V.: Těšetice-Kyjovice 4. Rondel osady lidu s moravskou malovanou keramikou. Brno, 56-64. 